\title{
Biodegradation of Glyphosate in Rhizospheric Soll Cultivated WITH Glycine max, Canavalia ensiformis E Stizolobium aterrimum ${ }^{1}$
}

\author{
Biodegradação de Glyphosate em Solo Rizosférico de Glycine max, Canavalia ensiformis e \\ Stizolobium aterrimum
}

\author{
SANTOS J.B. ${ }^{2}$, FERREIRA, E.A. ${ }^{3}$, FIALHO, C.M.T. ${ }^{4}$, SANTOS, E.A. ${ }^{5}$, GALON, L. ${ }^{6}$; CONCENÇO, G. ${ }^{7}$; \\ ASIAZÜ, I. ${ }^{8}$ and SILVA, A.A. ${ }^{9}$
}

\begin{abstract}
Biodegradation of glyphosate was evaluated in rhizospheric soil cultivated with Glycine max (soybean, var. BRS245-RR), Canavalia ensiformis and Stizolobium aterrimum. After these species were cultivated for 60 days, soil samples were collected, placed in flasks and treated with ${ }^{14} \mathrm{C}$-glyphosate. After 30 days of incubation, the total release rate of $\mathrm{C}-\mathrm{CO}_{2}$ was determined along with microbial biomass $(\mathrm{MBC})$, metabolic quotient $\left(\mathrm{qCO}_{2}\right)$, and degradation percentage of the radio-labeled glyphosate released as ${ }^{14} \mathrm{C}_{-} \mathrm{CO}_{2}$. A higher mass of rhizosphere-associated microorganisms was verified in the soil samples from pots cultivated with soybean, regardless of glyphosate addition. However, in the presence of the herbicide, this characteristic was the most negatively affected. Microorganisms from the C. ensiformis rhizosphere released a lower amount of ${ }^{14} \mathrm{C}-\mathrm{CO}_{2}$, while for those originated from $S$. aterrimum, the amount released reached $1.3 \%$ more than the total carbon derived from the respiratory activity. The rhizospheric soil from $S$. aterrimum also presented higher glyphosate degradation efficiency per microbial biomass unit. However, considering $\mathrm{qCO}_{2}$, the microbiota of the rhizospheric soil cultivated with soybean was more efficient in herbicide degradation.
\end{abstract}

Keywords: soil microbial activity, leguminous plants, transgenic soybean.

\begin{abstract}
RESUMO - Avaliou-se neste trabalho a degradação de glyphosate em solo rizosférico proveniente do cultivo de Glycine max (soja var. BRS245-RR), Canavalia ensiformis e Stizolobium aterrimum. Para isso, após o cultivo, em vasos, das citadas espécies por 60 dias, coletaram-se amostras de solo, as quais foram acondicionadas em frascos e tratadas com ${ }^{14} \mathrm{C}$-glyphosate. Após 32 dias de incubação, foram determinados a taxa de desprendimento total de $\mathrm{C}_{-} \mathrm{CO}_{2}$, a biomassa microbiana (MBC), o quociente metabólico $\left(q \mathrm{CO}_{2}\right)$ e a porcentagem de degradação do glyphosate radiomarcado liberado na forma de ${ }^{14} \mathrm{C}_{-} \mathrm{CO}_{2}$. Verificou-se a maiormassa de microrganismos associados à rizosfera em amostras de solo proveniente de vasos cultivados com a soja, independentemente da adição de glyphosate. Contudo, na presença do herbicida essa característica foi a mais afetada negativamente. Microrganismos da rizosfera de $\mathbf{C}$. ensiformis produziram a menor quantidade de ${ }^{14} \mathrm{C}_{-} \mathrm{CO}_{2}$ liberado, enquanto para aqueles provenientes da rizosfera de $\mathbf{S}$. aterrimum, a quantidade liberada atingiu 1,3\% a mais do total de carbono proveniente da atividade respiratória. $O$ solo rizosférico de $\mathbf{S}$. aterrimum também apresentou a maior eficiência de degradação de glyphosate porunidade de biomassa microbiana. Todavia, considerando o $\mathrm{qCO}_{2}$, a microbiota do solo rizosférico cultivado com a soja foi mais eficiente na degradação do herbicida.
\end{abstract}

Palavras-chave: atividade microbiana do solo, leguminosas, soja transgênica.

Recebido para publicação em 2.3.2009 e na forma revisada em 13.11.2009.

2 D.Sc., Professor da Universidade Federal dos Vales do Jequitinhonha e Mucuri, Faculdade de Ciências Agrárias, Campus II Rodovia MGT 367 - Km 583, nº 5000, Bairro Alto da Jacuba, 39100-000 Diamantina-MG; ${ }^{3}$ D. Sc. Pós-Doutorado em Fitotecnia DFT/UFV, Bolsista FAPEMIG, <evanderalves@yahoo.com.br>; ${ }^{4}$ Doutoranda do Dep. de Fitotecnia - DFT/UFV; ${ }^{5}$ M.Sc. em Fitotecnia - DFT/UFV; ${ }^{6}$ D. Sc., Prof ${ }^{\underline{o}}$ da Faculdade da Amazônia - FAMA, Vilhena-RO; ${ }^{7}$ Engo-Agr ${ }^{0}$, D.Sc., Pesquisador da Valley; ${ }^{8}$ Engo-Agr $^{0}$, D.Sc., DFT/UFV; ${ }^{9}$ Professor Associado - DFT/UFV, Bolsista em Produtividade de Pesquisa do CNPq, <aasilva@ufv.br>.

Planta Daninha, Viçosa-MG, v. 27, n. 4, p. 781-787, 2009 


\section{INTRODUCTION}

The use of chemicals to control pests, diseases and weeds has caused changes in soil population and microbial activity (Taiwo \& Oso, 1997). As a consequence, some of the microorganism populations capable of degrading these chemicals can be affected, causing their degradation in the environment. On the other hand, it has been observed that in soils cultivated with some plant species, a faster reduction of particular contaminants occurs, compared with soils cultivated with other species or soils without cultivation (Santos et al., 2007a).

Microbial degradation of chemicals in soil is the most important mechanism of soil decontamination (Fomsgaard, 1997), with such process being influenced by active microbial biomass and compound availability for biodegradation (Beigel et al., 1999).

Following the expansion of transgenic soybean cultivation, genetically modified to become resistant to glyphosate, the use of this herbicide has increased considerably. The reason for this is that this herbicide, previously non-selective and thus, applied only once at burndown before crop sowing, became selective for the genetically modified varieties. Because it is a highly efficient and low cost herbicide, it has been applied many times in the same area in a single crop (Santos et al., 2007a).

Glyphosate belongs to the chemical group of amino acid synthesis inhibitors and contains $\mathrm{N}$-(phosphonomethyl) glycine as active ingredient (Bridges, 2003). After its absorption by the plants, it is promptly translocated, along with photosynthates from the application points located on the leaves to distant sinks. In sensitive species, glyphosate inhibits the activity of the plastidic enzyme 5-enolpiruvilshikimate-3-phosphate synthase, (EPSPS) at the pre-corismate stage of the shikimate route (Shaner \& Bridges, 2003). This route, absent in animals, is fundamental in the metabolism of plants, fungi and bacteria for the biosynthesis of the essential amino acids phenylalanine, tyrosine and tryptophan (Hinchee et al., 1993). It has been estimated that $20 \%$ of the total photosynthesis-fixed carbon follow this route to synthesize the aromatic amino acids (Devine et al., 1993). This product is degraded by microorganisms in soil, involving molecule cleavage, with posterior production of amino methylphosphonic acid (AMPA) followed by water, carbon dioxide and phosphate (Forlani et al., 1999). Some indicators, such as soil basal respiration rate, may be indicative of biodegradation process (Souza et al., 1999, Tuffi Santos et al., 2005, Santos et al., 2007a).

It is believed that the vegetation present in an area could be determinant in improving the physical-chemical properties of the rhizosphere, promoting stable conditions with the constant supply of organic substrates and growth factors, favoring intense metabolic activity of the associated microbial populations (Santos et al., 2007a). Such rhizospheric activity interferes directly in the multiplication of the microorganisms and in their capacity to (co)metabolize the different compounds present in the medium. The interaction between roots and soil promotes proliferation of the microbial community in the rhizosphere region, due to exudation of the plant nutrients, such as amino acids and polysaccharides (Arthur et al., 2000).

As for degradation of the herbicides, the use of plant species and their associated microbiota for ambient decontamination - a process known as phytoremediation - has been increasing due to the need to recover areas and demand for more rigid environmental criteria in research (Santos et al., 2007a). Considering phytoremediation of herbicidecontaminated soils, the species Canavalia ensiformis and Stizolobium aterrimum have been reported as capable of accelerating the degradation of some molecules, including trifloxisulfuron-sodium (Procópio et al., 2007) and tebuthiuron (Pires et al., 2005b). According to Pires et al. (2005a) and Santos et al. (2007a), the microorganisms associated with the rhizosphere of these species affect the efficiency of the process of phytoremediation of contaminated soils. The objective of this study was to evaluate glyphosate degradation in rhizospheric soil samples collected in Glycine max, Canavalia ensiformis and Stizolobium aterrimum cultivations. 


\section{MATERIAL AND METHODS}

Soybean (Glycine max var. BRS 243 RR), wonderbean (Canavalia ensiformis) and velvetbean (Stizolobium aterrimum) were sown in vases with $6 \mathrm{dm}^{3}$ of soil classified as Red-Yellow Argisol, previously corrected for acidity and nutrient contents in relation to soybean culture, presenting organic matter content of $2.89 \%$. Fifty-five days after emergence, the entire plants were removed from the vases and samples of the soil adhered to the roots (rhizospheric soil) were collected for treatment application. Simultaneously, samples of the soil maintained under the same conditions, but without cultivation (non- rhizospheric soil), were collected as control.

In the laboratory, the soil samples were sieved, shade-dried for $24 \mathrm{~h}$, weighed (150 g) and then placed in $300 \mathrm{~mL}$ glass flasks. Sample moisture was adjusted to $70 \%$ of field capacity and a glyphosate solution at the concentration of $1.76 \mathrm{mg} \mathrm{kg}^{-1}$ equivalent to $3.36 \mathrm{~kg} \mathrm{ha}^{-1}$ of the technical product was added. Eight treatments (soil samples from soils cultivated with Glycine max, Canavalia ensiformis, Stizolobium aterrimum and non-cultivated soil) were evaluated, with these samples being treated and non-treated with glyphosate. The experiment was arranged in a completely randomized design in a factorial scheme $(4 \times 2)$ with four repetitions. The flasks were incubated for 32 days for evaluation of the $\mathrm{C}-\mathrm{CO}_{2}$ release rate, quantified every eight days.

To determine soil basal respiration rate after incubation of the samples, the $\mathrm{CO}_{2}$ evolved was captured in flasks containing $100 \mathrm{~mL}$ of $\mathrm{NaOH}\left(0.25 \mathrm{~mol} \mathrm{~L}^{-1}\right)$ under a continuous air flow system (free of $\mathrm{CO}_{2}$ and moisture). After each incubation period, indirect titration of $\mathrm{NaOH}$ with $\mathrm{HCl}\left(0.25 \mathrm{~mol} \mathrm{~L}^{-1}\right)$ was carried out and the excess $\mathrm{NaOH}$ that did not react to evolved $\mathrm{CO}_{2}$ was quantified (Anderson, 1982).

At the end of the incubation period, the microbial biomass carbon was determined by the method described by Vance et al. (1987), using a microwave oven (irradiation) (Islam \& Weil, 1988) instead of chloroform (fumigation) and the metabolic coefficient $\left(\mathrm{qCO}_{2}\right)$ through the relation between the $\mathrm{CO}_{2}(\mu \mathrm{g})$ accumulated and the total $\mathrm{C}$ of the microbial biomass $\left(\mu \mathrm{g} \mathrm{g}^{-1}\right)$.
This coefficient measures the microbial behavior instability as a function of the evaluation of the efficiency of carbon utilization; higher values of $\mathrm{qCO}_{2}$ could signify lower carbon utilization and, consequently higher loss to the atmosphere.

In duplicate, treatments were incubated containing the same amount of glyphosate, added by ${ }^{14} \mathrm{C}$-glyphosate (with radioactivity around 200,000 counts/minute-cpm) per sample. These treatments were evaluated separately after 30 days of incubation, by collecting $2 \mathrm{~mL}$ of $\mathrm{NaOH}$ solution added in $20 \mathrm{~mL}$ vials, containing $10 \mathrm{ml}$ of scintillation cocktail (Sigma Fluor ${ }^{\circledR}$ ), and submitted to homogenization. This was followed by placing the samples in a liquid scintillation spectrophotometer (Beckman 6500) for total radioactivity determination.

The radioactivity values expressed in CPM found in the aliquot from each soil sample were converted into percentage with relation to the total ${ }^{14} \mathrm{C}$-glyphosate initially applied. An indirect estimation of the glyphosate released as $\mathrm{C}-\mathrm{CO}_{2}$ was obtained. Analysis of variance was conducted, with the means, when significant, being compared by the Tukey test at $5 \%$ probability. The regression curves for $\mathrm{C}-\mathrm{CO}_{2}$ evolution from the soil samples during the incubation time as a function of the treatments were adjusted, with the coefficients being tested by the t-test at $5 \%$ probability.

\section{RESULTS AND DISCUSSION}

Based on the evaluation of $\mathrm{C}-\mathrm{CO}_{2}$ release rate from the soil, it was observed that 32 days were sufficient for a good estimation of the total accumulated, since at this time interval the total evolved gas tended to stabilize (Figure 1).

Regardless of herbicide addition, the soil from the soybean rhizosphere presented the highest quantity of released $\mathrm{C}-\mathrm{CO}_{2}$, with the total evolved being superior to $600 \mathrm{mg}$ at the end of the incubation period, accounting for more than four milligrams of $\mathrm{C}-\mathrm{CO}_{2} /$ gram of soil evaluated (Figure 1).

The highest decrease in $\mathrm{CO}_{2}$ release rate, with addition of the herbicide to the soil, was observed for C. ensiformis throughout the 
incubation period. An opposite behavior was observed in samples of non-cultivated soil (non-rhizospheric), which presented an increase of $46 \%$ in $\mathrm{C}-\mathrm{CO}_{2}$ released, at the end of the incubation period. Rhizospheric soil samples from $S$. aterrimum presented a similar response to that from the soybean, with a considerable increase of $13 \%$ in the presence of glyphosate (Figure 1).

The estimate of daily $\mathrm{CO}_{2}$ release rate did not present any difference for soybean and $S$. aterrimum in the presence of the herbicide (Table 1). For the other treatments, an increase was observed with herbicide addition
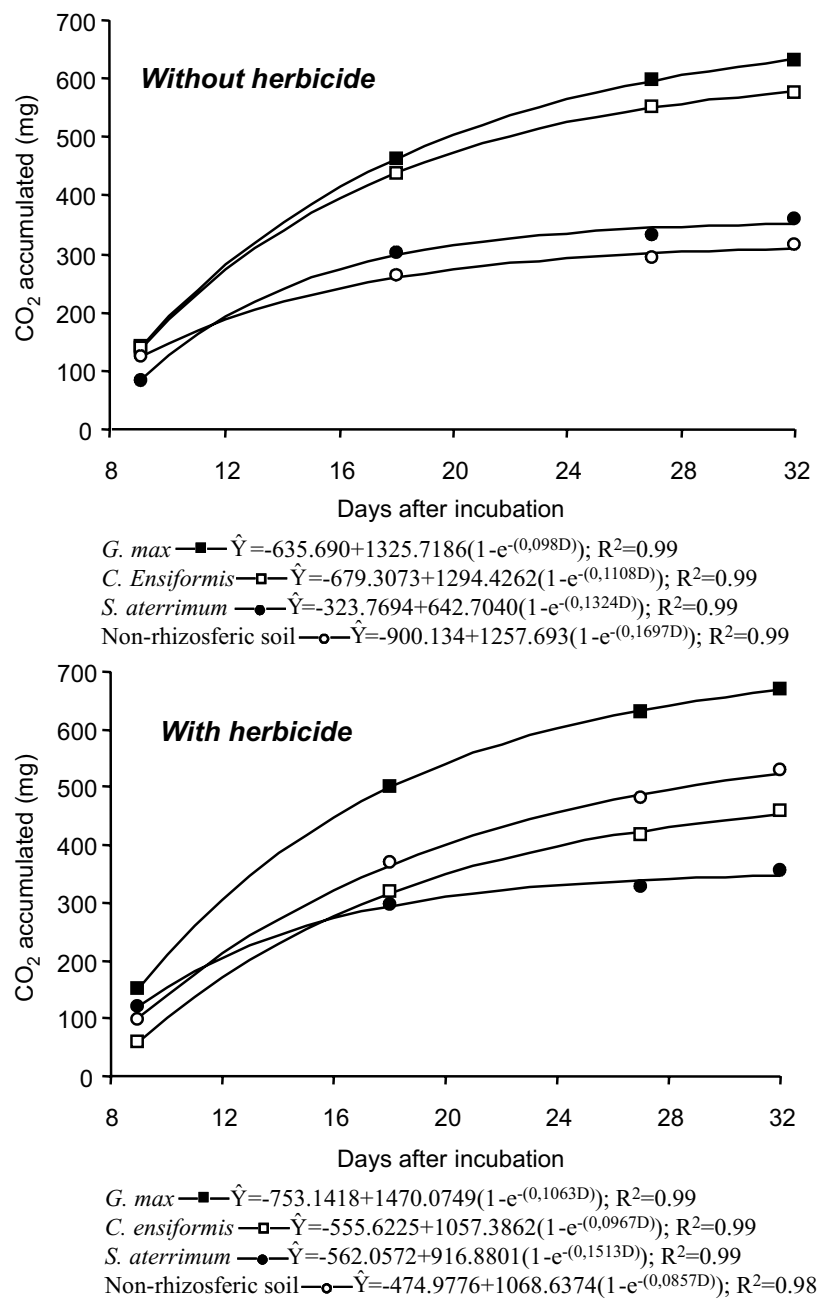

Figure 1 - $\mathrm{C}-\mathrm{CO}_{2}$ evolution from rhizospheric soil samples $(150 \mathrm{~g})$ incubated for 32 days, from the plant species Glycine max, Canavalia ensiformis and Stizolobium aterrimum and from non-rhizospheric soil, treated or nontreated with glyphosate $\left(1,76 \mathrm{mg} \mathrm{kg}^{-1}\right)$. in the non-rhizospheric soil samples and a decrease for the $C$. ensiformis soil samples (Table 1).

Similar alterations in total $\mathrm{C}-\mathrm{CO}_{2}$ released from the soil samples can be produced as a function of different management strategies adopted, with isolated evaluations of such characteristic becoming thus compromised. This "soil respiration" consists in a sensitive indicator of residue decomposition, metabolic turnover of organic carbon and soil ecosystem disturbances (Paul et al., 1999). However, high respiration rate, indicative of intense biological activity, can be a desirable characteristic when meaning rapid decomposition of organic residues, including pesticides, in plantavailable nutrients. The decomposition of the humic fraction of the soil can be unfavorable for many physical-chemical processes, such as aggregation, cation-exchange capacity and water retention (Tótola \& Chaer, 2002). Thus, higher $\mathrm{C}-\mathrm{CO}_{2}$ release may indicate an ecological disturbance or a high ecosystem productivity level.

Evaluation of $\mathrm{C}-\mathrm{CO}_{2}$ release as indicative of glyphosate biodegradation was carried out by Souza et al. (1999), who concluded that respiration increase caused by the addition of this herbicide was due to increased microbial activity, through the use of the molecule as a carbon source. However, Santos et al. (2007b), evaluating the effects of glyphosate application on RR soybean, observed that although the herbicide stimulated $\mathrm{CO}_{2}$ release from the rhizospheric soil samples, the biomass in the microorganisms was reduced, indicating reduced soil microbial activity.

In an attempt to overcome this problem, the microbial biomass carbon (MBC) was estimated to measure the amount of organic matter represented by the active biota. The MBC values varied both between the soils sampled and between the addition, or not, of glyphosate (Table 1). As already well documented in the literature, rhizosphere soils present an amount of microorganisms higher than that in non cultivated environments. In this study, the MBC values found in nonrhizospheric soil represented, on average, 19\% of those found in previously cultivated soil samples (Table 1). 
Table 1 - Values of released $\mathrm{CO}_{2}$, microbial biomass carbon $(\mathrm{MBC})$ and metabolic coefficient $\left(\mathrm{qCO}_{2}\right)$, estimated from rhizospheric soil samples of three plant species and non- rhizospheric soil, submitted or not to glyphosate application

\begin{tabular}{|c|c|c|c|c|c|c|}
\hline \multirow[b]{2}{*}{ Cultivated species } & \multicolumn{2}{|c|}{$\mathrm{C}-\mathrm{CO}_{2}$ (mg $\left.150 \mathrm{~g} \mathrm{soil}^{-1} \mathrm{day}^{-1}\right)$} & \multicolumn{2}{|c|}{$\operatorname{MBC}\left(\mathrm{mg} \mathrm{g}^{-1}\right)$} & \multicolumn{2}{|c|}{$\mathrm{qCO}_{2}\left(\mathrm{CO}_{2} \mathrm{MBC}^{-1}\right)$} \\
\hline & $\begin{array}{c}\text { without } \\
\text { herbicide }\end{array}$ & with herbicide & $\begin{array}{c}\text { without } \\
\text { herbicide }\end{array}$ & with herbicide. & $\begin{array}{c}\text { without } \\
\text { herbicide }\end{array}$ & with herbicide \\
\hline Glycine $\max$ & $19.72 \mathrm{Aa}^{1 / /}$ & $20.93 \mathrm{Aa}$ & $484.34 \mathrm{Aa}$ & $280.98 \mathrm{Ab}$ & $0.043 \mathrm{Ba}$ & $0.078 \mathrm{Ba}$ \\
\hline Canavalia ensiformis & $18.01 \mathrm{Aa}$ & $14.31 \mathrm{BCb}$ & $235.42 \mathrm{Ba}$ & $203.47 \mathrm{ABa}$ & $0.080 \mathrm{Ba}$ & $0.074 \mathrm{Ba}$ \\
\hline Stizolobium aterrimum & $8.82 \mathrm{Ba}$ & $11.11 \mathrm{Ca}$ & $255.18 \mathrm{Ba}$ & $166.96 \mathrm{ABa}$ & $0.069 \mathrm{Ba}$ & $0.041 \mathrm{Ba}$ \\
\hline Non-rhizosferic soil & $11.28 \mathrm{Bb}$ & $16.56 \mathrm{Ba}$ & $38.36 \mathrm{Ca}$ & $65.34 \mathrm{Ba}$ & $0.305 \mathrm{Aa}$ & $0.271 \mathrm{Aa}$ \\
\hline CV (\%) & \multicolumn{2}{|c|}{9.28} & \multicolumn{2}{|c|}{19.59} & \multicolumn{2}{|c|}{24.27} \\
\hline
\end{tabular}

${ }^{1 /}$ Means followed by the same lower case letters in the column do not differ by the Tukey test at $5 \%$ probability.

Among the plant species, regardless of glyphosate addition, soybean promoted the highest quantity of microorganisms in the rhizosphere, higher than $480 \mathrm{mg} \mathrm{g}^{-1}$ in the treatment without herbicide (Table 1). Soybean was also the only species presenting a lower quantity of $\mathrm{MBC}$ in the rhizospheric soil after herbicide addition (Table 1). Samples of soil from the $C$. ensiformis and $S$. aterrimum rhizosphere did not differ in $\mathrm{MBC}$, regardless of herbicide addition (Table 1).

The differential response for $\mathrm{MBC}$ in soybean rhizospheric soil may indicate a negative environmental impact of glyphosate on the soil microorganisms. Despite the high adsorption of this herbicide in the soil (Coutinho \& Mazo, 2005), toxic action on several groups of microorganisms, mainly in the soil, has been reported (Amarante Junior et al., 2002; Santos et al., 2005; Santos et al., 2007a).

The ratio between $\mathrm{C}-\mathrm{CO}_{2}$ release rate and the biomass of the microorganisms present is a safer way of evaluating microbial activity. This ratio, denominated metabolic coefficient $\left(\mathrm{qCO}_{2}\right)$ was proposed by Anderson \& Domsch (1985) and is directly related to the fact that as the biomass of the soil microorganisms becomes more efficient in utilizing the ecosystem resources, a lower quantity of $\mathrm{C}$ is lost through respiration and a higher proportion of this element is incorporated into the microbial tissues. Considering the rhizospheric environment as rich in microorganism biomass, it can be considered satisfactory the evaluation of the microbial biomass carbon and its relation with $\mathrm{C}-\mathrm{CO}_{2}$ production as indicative of microorganism activity in soil.

Evaluation of $\mathrm{qCO}_{2}$ confirmed the efficiency of the plant species in promoting a rhizospheric environment capable of decreasing the negative effect of glyphosate on the soil microorganisms. No differences were observed between the $\mathrm{qCO}_{2}$ estimated in the rhizospheric soil samples, regardless of the plant species cultivated or herbicide addition. However, absence of cultivation (nonrhizospheric soils) provided the soil a greater value for $\mathrm{qCO}_{2}$ (Table 1), indicating greater instability and, consequently, lower efficiency in carbon utilization.

Based on the $\mathrm{qCO}_{2}$ evaluation, it was confirmed that, although glyphosate addition promoted modifications in the $\mathrm{C}-\mathrm{CO}_{2}$ release rate of the soil and microbiota decrease (in the case of the soybean rhizospheric soil), the most negative effect seems to result from glyphosate action on soil with less amount of microorganisms (non-rhizospheric). Thus, the addition of radio marked glyphosate in the soil samples, allowing to estimate the herbicide amount converted into $\mathrm{C}-\mathrm{CO}_{2}$, led to conclude which plant species presents rhizospheric environment with greater capacity for molecule degradation.

Of the total ${ }^{14} \mathrm{C}$-glyphosate applied on the soil samples, those from the $C$. ensiformis rhizosphere presented the lowest percentage of ${ }^{14} \mathrm{C}-\mathrm{CO}_{2}$, evolved $(3,532 \%)$, with no differences being observed between the other soils $(4.6 \%$ on average) (Table 2$)$. However, considering the percentage of ${ }^{14} \mathrm{C}-\mathrm{CO}_{2}$ 
Table 2 - Total of ${ }^{14} \mathrm{C}-\mathrm{CO}_{2}(\%)$ originated from degradation of ${ }^{14} \mathrm{C}$-glyphosate by organisms present in the rhizosphere of three leguminous species and its relation with the $\mathrm{C}-\mathrm{CO}_{2}$ released and present in the microbial biomass

\begin{tabular}{|l|c|c|c|}
\hline \multicolumn{1}{|c|}{ Cultivated species } & Total ${ }^{14} \mathrm{C}_{-1} \mathrm{CO}_{2}(\%)$ & $\left({ }^{14} \mathrm{C}_{-1} \mathrm{CO}_{2} \mathrm{C}_{-} \mathrm{CO}_{2}{ }^{-1}\right) 100$ & ${ }^{14} \mathrm{C}-\mathrm{CO}_{2} \mathrm{MBC}^{-1}$ \\
\hline Glycine max & $4.516 \mathrm{a}^{1 /}$ & $0.674 \mathrm{~b}$ & $0.016 \mathrm{c}$ \\
\hline Canavalia ensiformis & $3.532 \mathrm{~b}$ & $0.771 \mathrm{~b}$ & $0.017 \mathrm{c}$ \\
\hline Stizolobium aterrimum & $4.754 \mathrm{a}$ & $1.337 \mathrm{a}$ & $0.028 \mathrm{~b}$ \\
\hline Non-rhizosferic soil & $4.620 \mathrm{a}$ & $0.872 \mathrm{~b}$ & $0.071 \mathrm{a}$ \\
\hline CV $(\%)$ & 7.82 & 12.22 & 13.55 \\
\hline
\end{tabular}

${ }^{1 /}$ Means followed by the same lower case letters in the column do not differ by the Tukey test at $5 \%$ probability.

produced in relation to the total $\mathrm{C}-\mathrm{CO}_{2}$ evolved from the soil samples, those from the $S$. aterrimum rhizosphere presented the highest results (1.337\% - Table 2). This result indicates that the soil originated from the rhizosphere of this species, in the presence of the herbicide, despite producing the lowest daily respiratory rate, has the highest relation between molecule carbon-herbicide and the total carbon respired. This does not necessarily imply greater efficiency in the degradation of the compound. Attempting to confirm such hypothesis, the ${ }^{14} \mathrm{C}-\mathrm{CO}_{2}$ released from the samples and the $\mathrm{MBC}$ were related, i.e., a new $\mathrm{qCO}_{2}$ was estimated based on the total carbon originated from herbicide degradation. In this case, the lowest values were observed for the soil samples from the soybean and C. ensiformis rhizospheres, showing higher efficiency of these species in reincorporating carbon in the microbial metabolism. Considering that $C$. ensiformis produced the lowest total percentage of ${ }^{14} \mathrm{C}-\mathrm{CO}_{2}$, soybean was the most efficient in promoting rhizospheric effect for glyphosate degradation.

In conclusion, it is possible to state that:

1. The importance of plant/microorganism association for glyphosate degradation in soil has been confirmed.

2. The efficiency of the process is dependent on variables such as the plant species present, but it can be considered higher in cultivated soil (with the species tested in this study) than in soil without the beneficial effects of the rhizosphere.

3. Among the species tested, soybean presented the best rhizospheric potential for glyphosate degradation. However, it is also the species having microbial biomass associated to its roots the most affected by the presence of the herbicide.

\section{ACKNOWLEDGMENTS}

We thank CNPq for its financial support.

\section{LITERATURE CITED}

AMARANTE JR., O. P. et al. Glifosato: propriedades, toxicidade, usos e legislação. Quimica Nova., v. 25, n. 4, p. 589-593, 2002.

ANDERSON, J. P. E. Soil respiration. In: PAGE, A.L.; MLLLER, R.H.; KEENEY, D.R. (Eds.). Methods of soil analysis: Chemical and microbiological properties. Madison, America Society of . Agronomy, 1982. Part 2. p. $831-871$

ANDERSON, T. H.; DOMSCH, K. H. Determination of ecophysiological maintenance carbon requirements of soil microorganisms in a dormant state. Biol. Fert. Soils, v. 1, n. 1, p. $81-89,1985$

ARTHUR, E. L. et al. Degradation of an atrazine and metolachlor herbicide mixture in pesticide-contaminated soils from two agrochemical dealerships in Iowa. Water Air Soil Poll., v. 119, n. 1, p. 75-90, 2000

BEIGEL, C. Degradation of formulated and unformulated triticonazole fungicide in soil: effect of application rate. Soil Biol. Biochem., v. 31, n. 4, p. 525-534, 1999

BRIDGES, D. C. Glyphosate-type herbicidas. In: Herbicide action course. West Lafayette: Purdue University, 2003. p. $501-513$

COUTINHO, C. F. B.; MAZO, L. H. Complexos metálicos com o herbicida glifosato: revisão. Quimica Nova, v. 28, n. 6, p. $1038-1045,2005$ 
DEVINE, M.; DUKE, S. O.; FEDTKE, C. Inhibition of aromatic amino acid synthesis. In: Physiology herbicide action. Englewood Cliffs: Prentice Hall, 1993. p. 252-263.

FOMSGAARD, I. S. Modelling the mineralization kinetics for low concentrations of pesticides in surface and subsurface soil. Ecol. Modelling, v. 102, n. 1, p. 175-208, 1997.

FORLANI, G. et al. Degradation of the phosphonate herbicide glyphosate in soil: evidence for a possible involvement of unculturable microorganism. Soil Biol. Biochem., v. 31, n. 7, p. 991-997, 1999.

HINCHEE, M. A. W. et al. Herbicide-tolerant crops. In: KUNG, S.; WU, R. (Eds.). Transgenic plants. San Diego: Academic Press, 1993. p. 243-263.

ISLAM, K. R.; WEIL, R. R. Microwave irradiation of soil for routine measurement of microbial biomass carbon. Biol. Fert. Soils, v. 27, n. 4, p. 408-416, 1988.

PAUL, E. A. et al. Evolution of $\mathrm{CO}_{2}$ and soil carbon dynamics in biologically managed, row-crop agroecosystems. Appl. Soil Ecol., v. 11, n. 1, p. 53-65, 1999.

PIRES, F. R. et al. Inferências sobre atividade rizosférica de espécies com potencial para fitorremediação do herbicida tebuthiuron. R. Bras. Ci. Solo, v. 29, n. 4, p. 627-634, 2005a.

PIRES, F. R. et al. Fitorremediação de solos contaminados com tebuthiuron utilizando-se espécies cultivadas para adubação verde. Planta Daninha, v. 23, n. 4, p. 711-717, $2005 b$.

PROCÓPIO, S. O. et al. Development of bean plants in soil contaminated with trifloxysulfuron-sodium after Stizolobium aterrimum and Canavalia ensiformis cultivation.

Planta Daninha, v. 25, n. 1, p. 87-96, 2007.
SANTOS, E. A. et al. Fitoestimulação por Stizolobium aterrimum como processo de remediação de solos contaminados por trifloxysulfuron-sodium. Planta Daninha, v. 25 , n. 2 , p. $259-265,2007 \mathrm{a}$.

SANTOS, J. B. et al. Tolerance of Bradyrhizobium strains to glyphosate formulations. Crop Protec., v. 24, n. 6, p. $543-547,2005$.

SANTOS, J. B. et al. Avaliação de formulações de glyphosate sobre soja Roundup Ready. Planta Daninha, v. 25, n. 1, p. $165-171,2007 b$.

SHANER, D.; BRIDGES, D. Inhibitors of aromatic amino acid biosyntesis (glyphosate). In: Herbicide action course. West Lafayette: Purdue University, 2003. p. 514-529.

SOUZA, A. P.; FERREIRA, F.A.; SILVA, A. A. Respiração microbiana do solo sob doses de glyphosate e de imazapyr.

Planta Daninha, v. 17, n. 3, p. 387-398, 1999.

TAIWO, L. B.; OSO, B. A. The influence of some pesticides on soil microbial flora in relation to changes in nutrient level, rock phosphate solubilization and $\mathrm{P}$ release under laboratory conditions. Agric. Ecosyst. Environ., v. 65, n. 1, p. 59-68, 1997.

TÓTOLA, M. R.; CHAER, G. M. Microrganismos e processos microbiológicos como indicadores da qualidade dos solos. In: ALVAREZ V., V. H. et al. (Eds.). Tópicos em ciência do solo. Viçosa, MG: Sociedade Brasileira de Ciência do Solo, 2002. v. 2. p. 195-276.

TUFFI SANTOS, L. D. et al. Exsudação radicular do glyphosate por Brachiaria decumbens e seus efeitos em plantas de eucalipto e na respiração microbiana do solo. Planta Daninha, v. 23, n. 1, p. 143-152, 2005.

VANCE, E. D.; BROOKES, P. C.; JENKINSON, D. S. An extraction method for measuring soil microbial biomass. Soil Biol. Biochem., v. 19, n. 6, p. 703-707, 1987. 